\title{
Antarctic yeasts: analysis of their freeze-thaw tolerance and production of antifreeze proteins, fatty acids and ergosterol
}

Pablo Villarreal, Mario Carrasco, Salvador Barahona, Jennifer Alcaíno, Víctor Cifuentes and Marcelo Baeza* (1)

\begin{abstract}
Background: Microorganisms have evolved a number of mechanisms to thrive in cold environments, including the production of antifreeze proteins, high levels of polyunsaturated fatty acids, and ergosterol. In this work, several yeast species isolated from Antarctica were analyzed with respect to their freeze-thaw tolerance and production of the three abovementioned compounds, which may also have economic importance.

Results: The freeze-thaw tolerance of yeasts was widely variable among species, and a clear correlation with the production of any of the abovementioned compounds was not observed. Antifreeze proteins that were partially purified from Goffeauzyma gastrica maintained their antifreeze activities after several freeze-thaw cycles. A relatively high volumetric production of ergosterol was observed in the yeasts Vishniacozyma victoriae, G. gastrica and Leucosporidium creatinivorum, i.e., 19, 19 and $16 \mathrm{mg} \mathrm{I}^{-1}$, respectively. In addition, a high percentage of linoleic acid with respect to total fatty acids was observed in V. victoriae (10\%), Wickerhamomyces anomalus (12\%) and G. gastrica (13\%), and a high percentage of alpha linoleic acid was observed in L. creatinivorum (3.3\%).

Conclusions: Given these results, the abovementioned yeasts are good candidates to be evaluated for use in the production of antifreeze proteins, fatty acids, and ergosterol at the industrial scale.
\end{abstract}

Keywords: Antifreeze proteins, Polyunsaturated fatty acids, Ergosterol, Antarctic yeasts, Freeze-thaw tolerance

\section{Background}

Currently, there is a well-established and increasing global market for biomolecules used in industrial, medical, and biotechnological fields, such as antifreeze compounds, polyunsaturated fatty acids (PUFAs) and ergosterol. Among the antifreeze compounds, antifreeze proteins (AFPs) and ice-binding proteins (IBPs) have great biotechnological potential in the cryopreservation of mammalian and plant cells [1], preparation of frozen food and the cryopreservation of transplant organs [2, 3]. AFPs were first described almost four decades ago in Antarctic marine fishes [4] and have subsequently been discovered in a broad range of organisms, including snow mold fungi [5], sea ice diatoms [6], snow algae [7], bacteria [8-11] and

\footnotetext{
*Correspondence: mbaeza@uchile.c

Departamento de Ciencias Ecológicas, Facultad de Ciencias, Universidad de
} Chile, Santiago, Chile

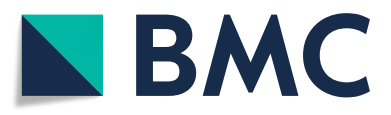

(อ) The Author(s). 2018 Open Access This article is distributed under the terms of the Creative Commons Attribution 4.0 International License (http://creativecommons.org/licenses/by/4.0/), which permits unrestricted use, distribution, and reproduction in any medium, provided you give appropriate credit to the original author(s) and the source, provide a link to the Creative Commons license, and indicate if changes were made. The Creative Commons Public Domain Dedication waiver (http://creativecommons.org/publicdomain/zero/1.0/) applies to the data made available in this article, unless otherwise stated. yeasts [12-14]. AFPs are a large, non-homologous protein family with diverse structures $[15,16]$ and a common ability to bind to ice and modify its morphology and to inhibit ice recrystallization $[17,18]$, reducing cell injury due to ice formation. The isolation and purification of AFPs are laborious and costly processes, which limits their use at industrial scales $[3,18]$. Thus, there has been a continuous search for cheaper sources of AFPs.

PUFAs are amphipathic molecules that have essential biological functions, such as the maintenance of cell membrane fluidity and permeability and enzyme activity, among others functions $[19,20]$. Furthermore, the importance of PUFAs in the adaptation of organisms that inhabit cold environments or in the response to cold stress has been demonstrated [21-24]. PUFAs have also gained attention due to their roles in human health, therapeutics, and nutrition [25-27], and PUFAs are 
currently commercially obtained from plant seeds and some marine sources $[25,26]$. Sterols are essential lipids in most eukaryotic cells that have important structural and signaling functions, with cholesterol, phytosterol, and ergosterol being the primary sterols present in vertebrates, plants and fungi, respectively [28]. Ergosterol is important economically, mainly because it is a precursor of vitamin D2 and has the potential for development of anticancer drugs since it inhibits the growth of different human cancer cell lines in vitro [29-32]. Thus, efforts have been made to improve the production of ergosterol in the yeast Saccharomyces cerevisiae for large-scale production [33, 34].

Due to the broad spectrum of applications for antifreeze compounds, ergosterol, and PUFAs, there has been a continuous search for attractive and novel sources of these products for their commercial production, such as microorganisms. Microorganisms have high growth rates and simple nutritional requirements. In addition, the ability to genetically manipulate and to perform large-scale fermentations with microorganisms makes them attractive model organisms. Among microorganisms, yeasts that thrive in extreme cold environments are of special interest because they naturally produce the previously mentioned compounds as part of their adaptive mechanisms to cold and freezing conditions $[35,36]$. Because Antarctica has one of the driest and coldest climates on Earth, yeasts that thrive in Antarctica are good candidate sources of the previously mentioned compounds.

In previous studies, we reported the isolation and characterization of yeast species from different terrestrial habitats of Antarctica, focusing on the production of economically attractive hydrolytic enzymes and compounds, such as carotenoid pigments and mycosporines [37-43]. In this work, we analyzed the production of extracellular AFPs, PUFAs, and ergosterol in these Antarctic yeast species. For each type of compound, a potentially suitable yeast source was identified that could be a good candidate for further studies to evaluate its potential use in the commercial production of these compounds.

\section{Methods}

\section{Yeasts and culture conditions}

The yeast species used in this work are listed in Table 1 and were isolated and identified from soil and water samples from King George Island in the sub-Antarctic region [43]. The culture media used in this study were as follows: yeast-malt medium (YM), $0.3 \%$ yeast extract, $0.3 \%$ malt extract, $0.5 \%$ peptone; yeast nitrogen base (YNB), $0.67 \%$ yeast nitrogen base without amino acids, $0.5 \%$ peptone; Vogel's minimal medium (VM), $13 \% \mathrm{Na}_{3}$ citrate $2 \mathrm{H}_{2} \mathrm{O}$, $12.6 \% \quad \mathrm{KNO}_{3}, \quad 14.4 \% \quad\left(\mathrm{NH}_{4}\right) \mathrm{H}_{2} \mathrm{PO}_{4}, \quad 8 \% \quad \mathrm{KH}_{2} \mathrm{PO}_{4}, \quad 1 \%$
Table 1 Yeast species used in this work

\begin{tabular}{ll}
\hline Species & $\mathrm{T}\left({ }^{\circ} \mathrm{C}\right)$ \\
\hline Candida parapsilosis & 30 \\
Candida sake & 22 \\
Cryptococcus gastricus (Goffeauzyma gastrica) & 22 \\
Cryptococcus gilvescens (Goffeauzyma gilvescens) & 22 \\
Cryptococcus victoriae (Vishniacozyma victoriae) & 22 \\
Dioszegia fristingensis & 22 \\
Leucosporidiella creatinivora (Leucosporidium creatinivorum) & 22 \\
Leucosporidiella fragaria (Leucosporidium fragarium) & 22 \\
Metschnikowia bicuspidata & 10 \\
Mrakia blollopis & 15 \\
Mrakia gelida & 22 \\
Mrakia sp. & 22 \\
Rhodotorula glacialis (Phenoliferia glacialis) (T11Rs) & 22 \\
Rhodotorula glacialis (Phenoliferia glacialis) (T8Rg) & 22 \\
Rhodotorula laryngis (Cystobasidium laryngis) & 22 \\
Rhodotorula mucilaginosa & 30 \\
Sporidiobolus salmonicolor & 22 \\
Wickerhamomyces anomalus & 30 \\
\hline The curent taxonomic classfication is given in parathesis. best
\end{tabular}

The current taxonomic classification is given in parenthesis. $T$, best temperature for growth

$\mathrm{MgSO}_{4} \cdot 7 \mathrm{H}_{2} \mathrm{O}, 10 \mu \mathrm{l}$ trace element solution, and $5 \mu \mathrm{l}$ $0.1 \mathrm{mg} \mathrm{ml}^{-1}$ biotin solution. The media were supplemented with $2 \%$ glucose and contained $1.5 \%$ agar when agar-solidified medium was used. The yeasts were grown at various temperatures according to the optimal growth temperature for each species (Table 1).

\section{Tolerance of yeast to freeze-thaw cycles}

The yeast strains were grown until the late log-phase of growth in YM medium supplemented with $2 \%$ glucose, after which $15 \mathrm{ml}$ of each culture was aliquoted in separate falcon tubes. Each freeze-thaw cycle (FTC) consisted of freezing the culture aliquot in the falcon tube at $20{ }^{\circ} \mathrm{C}$ for $12 \mathrm{~h}$, after which it was thawed at $22{ }^{\circ} \mathrm{C}$ for $30 \mathrm{~min}$. Sample aliquots were collected after each FTC, and the number of viable cells remaining was determined. The percentage of yeast survival was calculated by comparison to the number of viable cells in the original culture.

\section{Extraction and purification of secreted proteins}

Yeast cultures $(100 \mathrm{ml})$ were centrifuged at $8000 \mathrm{~g}$ for $10 \mathrm{~min}$ at $4{ }^{\circ} \mathrm{C}$, after which the supernatants were filtered through a sterile $0.45-\mu \mathrm{m}$ pore size polyvinylidene fluoride membrane (Millipore, Billerica, MA, USA). Then, ammonium sulfate was added stepwise to cell-free supernatants to reach $80 \%$ saturation, followed by incubation at $4{ }^{\circ} \mathrm{C}$ for $2 \mathrm{~h}$ with orbital agitation. The protein 
pellets obtained after centrifugation at $10,000 \mathrm{~g}$ at $4{ }^{\circ} \mathrm{C}$ for $10 \mathrm{~min}$ were suspended in $5 \mathrm{ml}$ of water and dialyzed against $1000 \mathrm{ml}$ of water for $12 \mathrm{~h}$ with 2 changes of water using a dialysis bag with a $10-\mathrm{kDa}$ cut-off. The same procedure was performed for each step of sample fractioning by ammonium sulfate precipitation from 20 to $80 \%$ saturation. For chromatographic purification, a Superdex 75 10/300 GL column (Merck, Darmstadt, Germany) equilibrated with $20 \mathrm{mM}$ sodium phosphate buffer (pH 7.0) and $150 \mathrm{mM} \mathrm{NaCl}$ was used as the mobile phase with a flow rate of $0.2 \mathrm{ml} \mathrm{min}{ }^{-1}$. The chromatographic runs were performed using an AKTA prime purification system (General Electric, New York, USA), with protein elution monitored at $280 \mathrm{~nm}$, and $0.2-\mathrm{ml}$ fractions were collected. Fractions corresponding to protein peaks were dialyzed as described above and were tested for antifreeze activities. The protein profile was determined by $15 \%$ SDS-PAGE, and proteins were quantified using a BCA kit (Pierce BCA protein assay kit, Thermo Scientific, IL, USA) according to the manufacturer's instructions. To assess protein glycosylation, the SDS-PAGE gels were stained using a Pierce glycoprotein staining kit (Thermo Scientific, IL, USA) according to the manufacturer's instructions.

\section{Evaluation of the antifreeze properties of protein samples}

The antifreeze properties of protein samples were evaluated by determining the inhibition of ice recrystallization using a method based on the aggregation of gold nanoparticles [44, 45]. Briefly, gold nanoparticles (AuNP) were synthesized by heating $300 \mathrm{mM} \mathrm{HAuCl} \mathrm{H}_{4} \cdot 3 \mathrm{H}_{2} \mathrm{O}$ until it began to boil, after which $2 \mathrm{ml}$ of $30 \mathrm{mM}$ sodium citrate dehydrate was added and the solution was boiled for 20 min and then cooled to ambient temperature with continuous stirring. Next, one volume of 2-mercaptosuccinic acid was added, and the mixture was agitated for $1 \mathrm{~h}$ at ambient temperature. To assess the antifreeze properties of protein samples, the AuNP solution and a protein sample $(50 \mu \mathrm{l}$ each) were mixed in one well of a microtiter plate, which was frozen at $-20^{\circ} \mathrm{C}$ for $1 \mathrm{~h}$ and then thawed at $22{ }^{\circ} \mathrm{C}$ for $30 \mathrm{~min}$. The absorbance spectrum from 400 to $800 \mathrm{~nm}$ was recorded using an Epoch microplate spectrophotometer (Biotek, Winooski, VT, USA) before and after freezing. The $A_{520} / A_{650}$ ratio was calculated before (BFR) and after (AFR) the freezing step, and the BFR/AFR ratio was determined for each sample. The closer the $\mathrm{BFR} / \mathrm{AFR}$ value is to one, the greater the antifreeze activity of the tested sample.

\section{Sterol extraction and identification}

Sterols were extracted using the method described by Shang et al. [46]. First, the cell pellet from $10 \mathrm{ml}$ of yeast culture was mixed with $4 \mathrm{~g}$ of $\mathrm{KOH}$ and $16 \mathrm{ml}$ of $60 \%$ ethanol. After incubation at $80{ }^{\circ} \mathrm{C}$ for $2 \mathrm{~h}$, sterols were extracted with $10 \mathrm{ml}$ of petroleum ether and quantified at $282 \mathrm{~nm}$ using a molar extinction coefficient of $11,900 \mathrm{~cm}^{-1} \mathrm{M}^{-1}$ [47]. For the reverse phase high-pressure liquid chromatography (RP-HPLC) analysis, samples were dried at $25{ }^{\circ} \mathrm{C}$ and suspended in $200 \mu \mathrm{l}$ acetone. Samples were then loaded onto a LiChroCART RP18 125-4 column (Merck KGaA, Darmstadt, Germany) using methanol:water $(97: 3, v / v)$

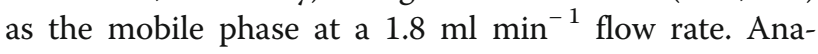
lyses were performed in an LC-10ATVP Shimadzu instrument equipped with a diode array detector, and sterols were detected at $280 \mathrm{~nm}$.

\section{Analysis of fatty acid composition}

Yeasts were cultured in 81 of YM medium supplemented with $1 \%$ glucose in a BIOFLO 415 fermenter (New Brunswick Scientific, Edison, NJ, USA) until the stationary phase of growth was reached. Cell pellets were collected by centrifugation at $4000 \mathrm{~g}$ at $4{ }^{\circ} \mathrm{C}$ for $5 \mathrm{~min}$ and were thoroughly washed with distilled water. Oil extraction and analysis were conducted according to the method described by Bligh and Dyer [48] and the AOAC official method 969.33, which were performed by an external service (ANALAB CHILE S.A., www.analab.cl).

\section{Results}

\section{Tolerance to freeze-thaw cycles}

Yeast cultures were subjected to FTCs as described in the Materials and Methods, although the freezing time varied for some yeast species that showed no loss of survival between successive FTCs. As shown in Fig. 1, the freeze-thaw tolerance varied among the studied yeasts species: Dioszegia fristingensis, Leucosporidium creatinivorum, Candida parapsilosis, and Vishniacozyma victoriae exhibited the highest tolerance, displaying survival percentages of 8,53 , and $1 \%$, respectively, after six FTCs. By contrast, the yeasts Wickerhamomyces anomalus, Goffeauzyma gastrica, Mrakia gelida, and Mrakia blollopis showed the lowest freeze-thaw tolerance, as less than $0.1 \%$ of cells survived after two FTCs. The remainder of the assayed yeast species showed moderate freeze-thaw tolerance compared to those mentioned above. For comparative purposes, some yeasts with high, moderate and low freeze-thaw tolerance were selected for further study.

In the previous assay, yeasts were cultivated at their optimal growth temperature before being submitted to FTCs. We then evaluated whether incubation at a lower temperature prior to FTCs would improve their freeze-thaw tolerance. To test this possibility, L. creatinivorum and $G$. gastrica, species with high and low freeze-thaw tolerances, respectively, were cultured at their optimal growth temperature until the late exponential phase of growth was reached. Next, the yeasts were 


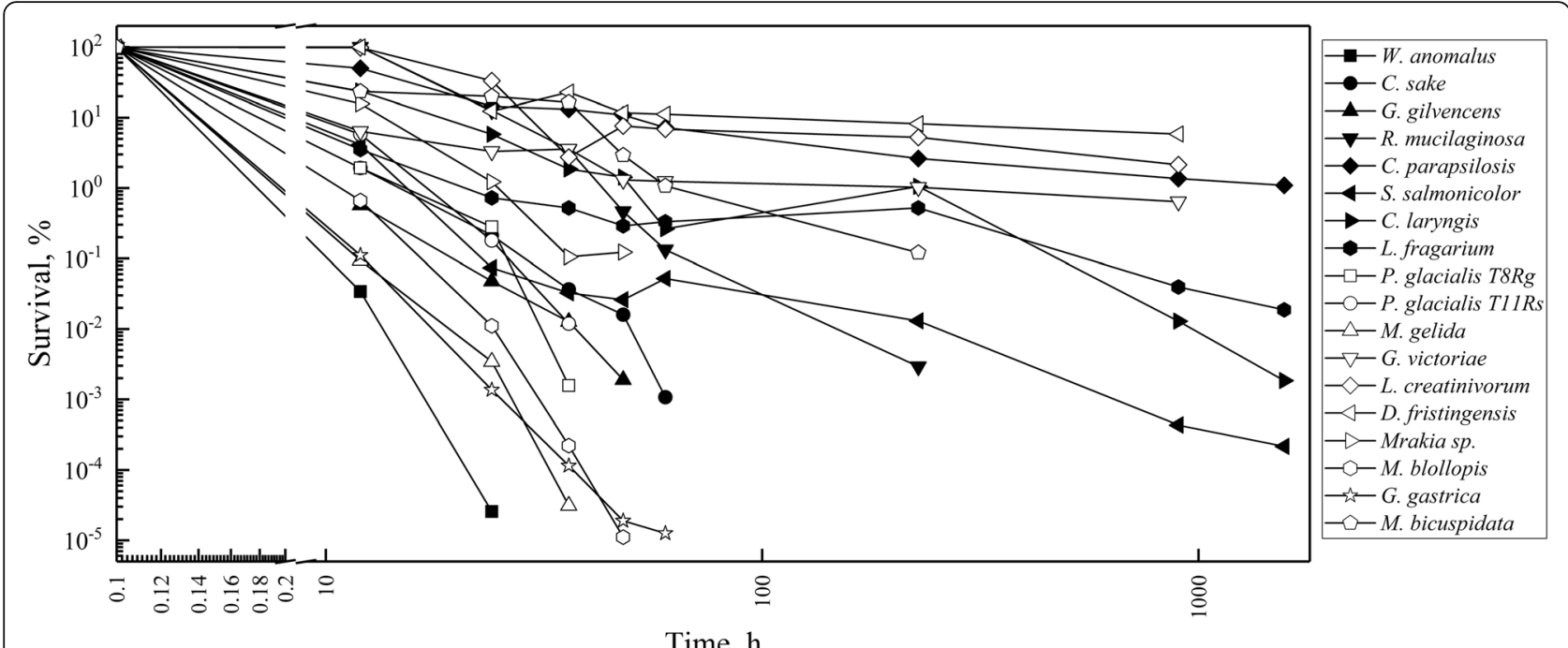

Time, $\mathrm{h}$

Fig. 1 Tolerance to freeze-thaw cycles. Yeast cultures were frozen at $-20^{\circ} \mathrm{C}$ and then thawed at $22^{\circ} \mathrm{C}$. The freezing time varied according to the results obtained for each yeast species in successive FTCs. The values are the average of three determinations. The error bars were not included to maintain the clarity of the plot

incubated at $4{ }^{\circ} \mathrm{C}$ for 24,48 and $72 \mathrm{~h}$ before being subjected to FTCs. No freeze-thaw tolerance improvement was observed for either strain in all assays performed (data not shown).

\section{Evaluation of the antifreeze properties of proteins secreted by yeasts and their purification}

Total extracellular proteins were obtained from cell-free supernatants of yeast cultures, after which they were analyzed by SDS-PAGE and assayed for their antifreeze properties (Additional file 1: Figure S1). The BFR/AFR ratio was also determined for $1 \mu \mathrm{g} \mathrm{ml}{ }^{-1}$ bovine serum albumin (BSA) (used as the control) and for protein samples extracted from non-inoculated YM medium, which had values of 0.24 and 0.51 , respectively. Protein samples with a BFR/AFR ratio higher than those observed for BSA and non-inoculated YM medium were obtained from L. creatinivorum (0.82), C. parapsilosis (0.94) and G. gastrica (0.91). The components of YM medium such as proteins and pigments co-precipitated when the culture supernatant protein samples were obtained, which could influence the determination of antifreeze properties. For this reason, the yeast biomass and extracellular protein yields of the three yeast species mentioned above were compared when cultivated in YM medium and the less complex Vogel, YNB, and YNB-P media. Although the results obtained using the last three media were lower than those obtained using the YM medium (Additional file 2: Table S1), the best results were obtained using the YNB-P medium supplemented with $2 \%$ glucose for all three yeast species. Therefore,
YNB-P supplemented with $2 \%$ glucose was selected for further protein purification steps and analysis.

Figure 2 shows the protein content $(\geq 10 \mathrm{kDa}$ according to the cut-off of the dialysis bag used in the purifications) and antifreeze activity analyses of protein samples fractionated using different concentrations of ammonium sulfate. The highest BFR/AFR values were observed for the protein fractions obtained from the $L$. creatinivorum, C. parapsilosis and G. gastrica protein samples at 80,60 and $60 \%$ ammonium sulfate saturation, respectively. These fractions were subjected to additional purification steps using several chromatographic methods, and the best results were obtained using cationic exchange chromatography (Fig. 3). A protein band with an rMW of approximately 100,000 (S100) and two other bands with an rMW less than 35,000 (S35) (box A in Fig. 3) could be distinguished in the protein samples from G. gastrica, all of which are glycosylated proteins (box B in Fig. 3). For the protein samples from the yeasts L. creatinivorum and C. parapsilosis, no clear protein bands were observed (data not shown). Interestingly, no antifreeze activity could be detected when the protein samples containing the S100 or the S35 protein bands from G. gastrica were assayed independently. However, the antifreeze activity was restored and reached a similar level as the original protein sample (the $60 \%$ ammonium sulfate saturation fraction) when fractions containing each protein band were mixed (Fig. 4a). The protein mix was subjected to several FTCs and assessed for antifreeze activity after each cycle. As shown in Fig. 4b, the protein mix maintained its antifreeze activity until the sixth FTC but decreased rapidly after additional cycles. 


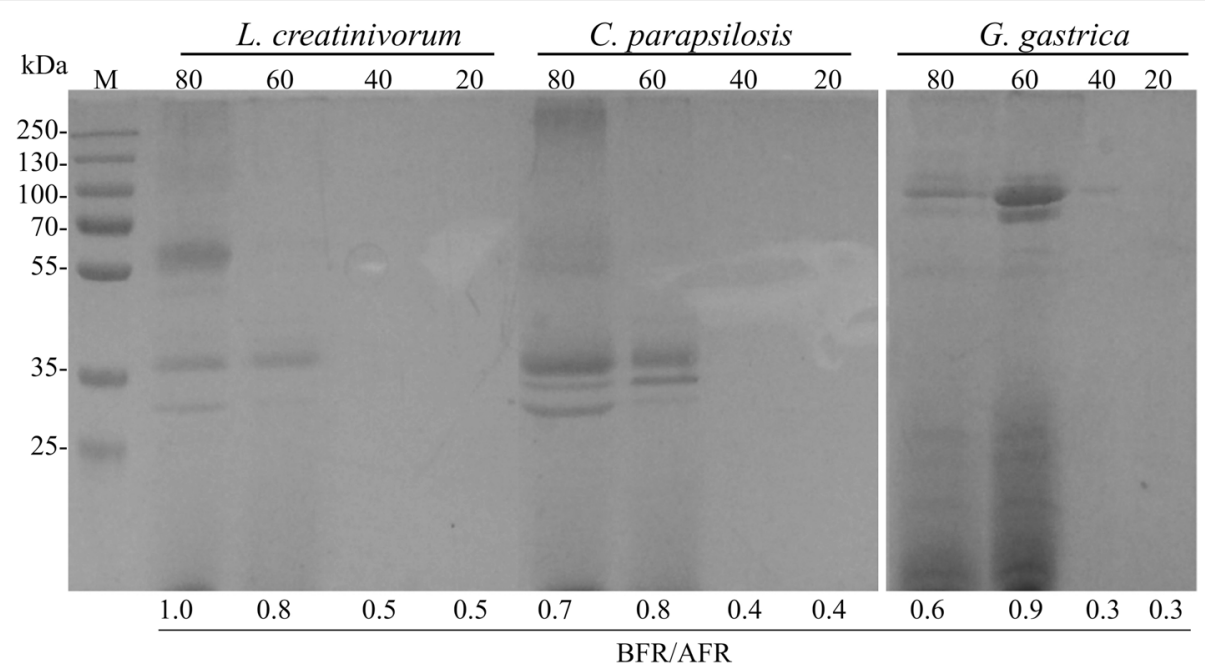

Fig. 2 Fractioning and antifreeze properties of proteins secreted by yeasts. The different yeast species were cultured in YNB-P medium until the stationary growth phase. The proteins were fractionated from cell-free supernatants using increasing saturation percentages of ammonium sulfate (indicated at the top of the SDS-PAGE gels). The antifreeze activity (BFR/AFR) of each protein fraction is indicated at the bottom of each gel well. $M$, protein molecular marker

\section{Fatty acids}

The results from the fatty acid analyses are summarized in Table 2, including the composition details for PUFAs. Details for the composition of saturated and monounsaturated FAs are included in Additional file 3: Table S2. Among the identified monounsaturated FAs, higher percentages of oleic acid (C18:1) were observed in Dioszegia fristingensis (57\%), Rhodotorula mucilaginosa (57\%) and
Cystobasidium laryngis (63\%), corresponding to 35, 34 and $42 \%$ of their total FAs, respectively. Eicosanoic acid (EPA, C20:1) was present at high percentages in R. mucilaginosa (1.7\%) and C. laryngis (2.1\%), representing 1 and $1.4 \%$ of total FAs, respectively. With respect to PUFAs, the highest percentages, from 30 to $37 \%$, were observed in the yeasts W. anomalus, G. gastrica, $V$. victoriae and L. creatinivorum. Among PUFAs, the highest

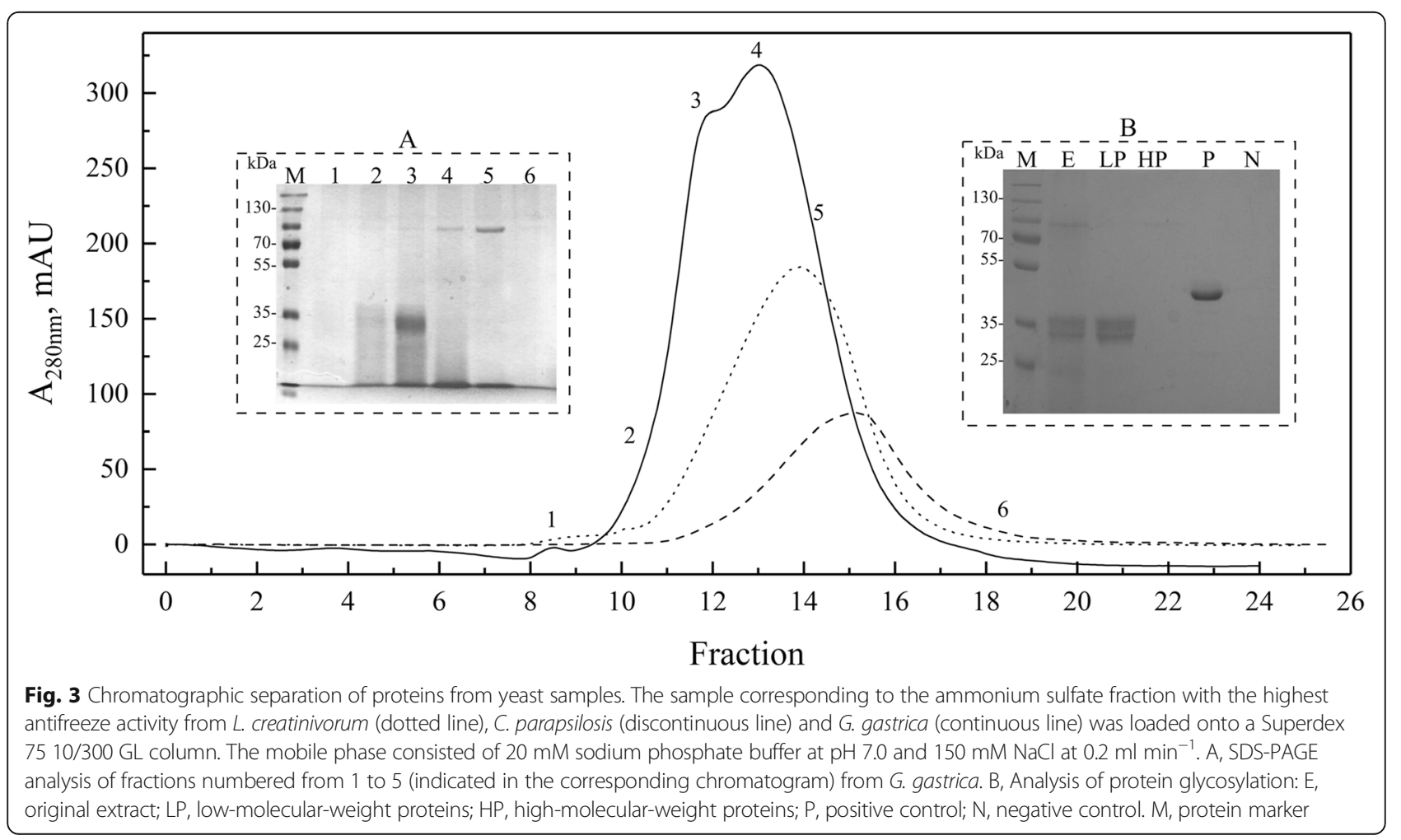



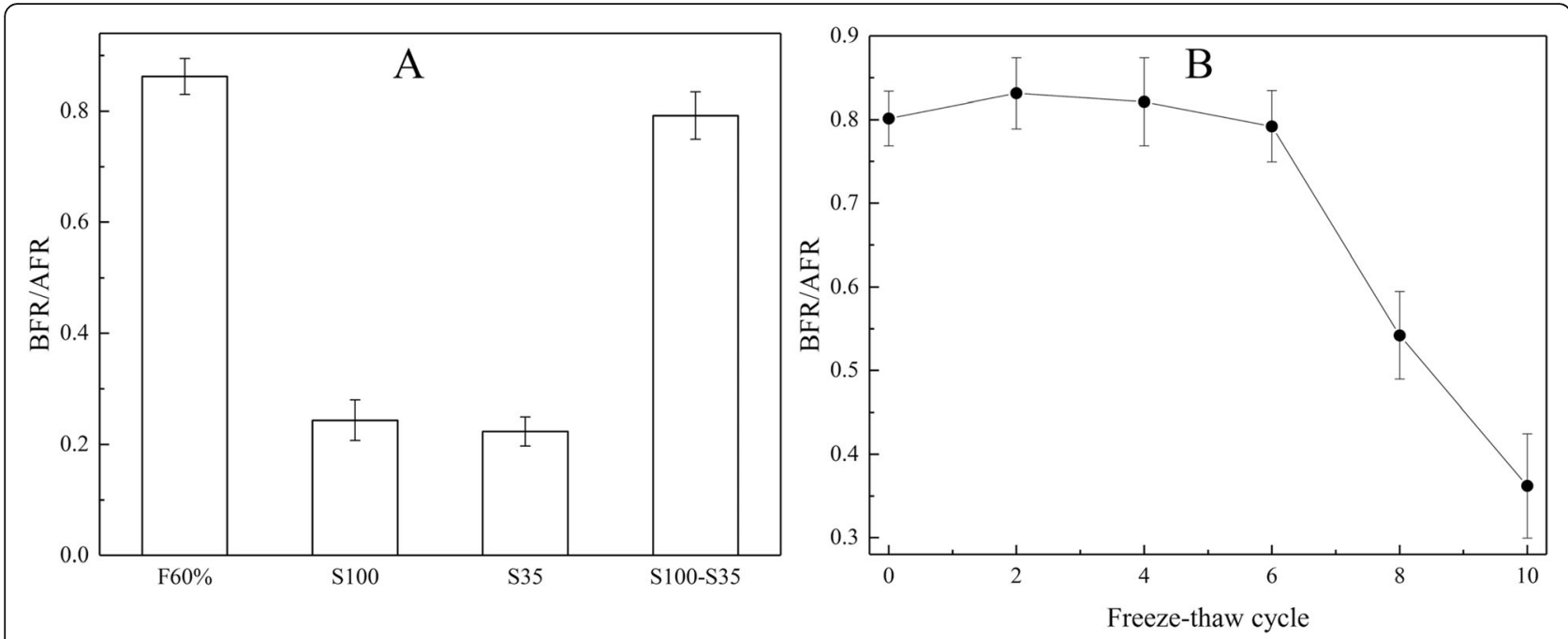

Fig. 4 Freeze-thaw tolerance of proteins from G. gastrica. A, antifreeze properties of protein samples corresponding to fractions: 60\% ammonium sulfate (F60\%), rMW 100,000 (S100), rMW lower than 35,000 (S35) and a mix of S100 and S35 (S100-S35). B, antifreeze properties of S100-S35 determined after several freeze-thaw cycles. The values are the average of three determinations, and the error bars correspond to the standard deviation

percentages of linoleic acid (LA, C18:2) were observed in G. victoriae (30\%), W. anomalus (33\%) and G. gastrica (35\%), representing 10, 12 and $13 \%$ of total FAs, respectively. The highest percentage of alpha linoleic acid (ALA, 18:3) was observed in L. creatinivorum (11\%), corresponding to $3.3 \%$ of total FAs.

\section{Extraction and identification of sterols}

The yeast species were grown in YM medium supplemented with glucose at their optimal growth temperatures until the stationary phase of growth, and yeast pellets were obtained. Sterols were extracted from the pelleted yeast cells and were quantified and analyzed by
RP-HPLC. The yeasts with the highest sterol contents (higher than $3 \mathrm{mg} \mathrm{g}^{-1}$ dry weight) were $M$. blollopis, $L$. creatinivorum, D. fristingensis and M. gelida (Table 3). The effect of cultivation temperature on the production of sterols was evaluated from 10 to $30{ }^{\circ} \mathrm{C}$ for yeasts with high ( $M$. blollopis and $L$. creatinivorum) and low (R. mucilaginosa) sterol contents. No significant changes in total sterol contents for either yeast were observed when they were cultivated at the different temperatures (Fig. 5).

The sterol composition of the different yeast species was analyzed by RP-HPLC. In all cases, a major peak was observed that corresponded to ergosterol according

Table 2 Fatty acids composition in Antarctic yeasts

\begin{tabular}{|c|c|c|c|c|c|c|}
\hline \multirow[t]{3}{*}{ Yeast species } & \multicolumn{6}{|c|}{ Fatty acids, \% } \\
\hline & \multirow[t]{2}{*}{ Saturated } & \multirow[t]{2}{*}{ Monounsaturated } & \multicolumn{4}{|c|}{ Polyunsaturated } \\
\hline & & & Total & $\mathrm{LA}(\mathrm{C} 18: 2)$ & $\operatorname{ALA}(C 18: 3)$ & $\mathrm{C} 20: 2<$ \\
\hline L. creatinivorum & 23.1 & 42.7 & 30.2 & 18.6 & 10.8 & 0.8 \\
\hline C. parapsilosis & 44.9 & 20.0 & 16.8 & 13.5 & 1.9 & 1.4 \\
\hline V. victoriae & 37.3 & 29.6 & 33.1 & 30.1 & 2.2 & 0.8 \\
\hline D. fristingensis & 11.0 & 60.9 & 28.1 & 21.8 & 6.3 & ND \\
\hline R. mucilaginosa & 15.5 & 60.0 & 20.6 & 17.8 & 2.2 & 0.6 \\
\hline C. laryngis & 20.2 & 67.1 & 12.1 & 11.5 & nd & 0.6 \\
\hline S. salmonicolor & 43.7 & 41.9 & 14.4 & 14.4 & nd & nd \\
\hline W. anomalus & 21.9 & 37.3 & 36.7 & 33.1 & 3.1 & 0.5 \\
\hline G. gastrica & 13.3 & 43.3 & 36.4 & 34.9 & nd & 1.5 \\
\hline M. gelida & 49.3 & 38.1 & 12.6 & 12.6 & nd & nd \\
\hline M. blollopis & 44.0 & 29.7 & 26.3 & 24.5 & 0.7 & 1.2 \\
\hline
\end{tabular}

nd not detected, LA(C18:2) linoleic acid, ALA(C18:3) alpha linolenic acid, C20:2 < PUFAs of 20 carbons with more than two unsaturation 
Table 3 Analysis of sterols content in different yeast species

\begin{tabular}{lll}
\hline Yeast species & Biomass & Total $^{\mathrm{a}}, \mathrm{mg} \mathrm{g}^{-1}$ \\
\hline L. creatinivorum & $4.0 \pm 0.1$ & $4.03 \pm 0.12^{*}$ \\
C. parapsilosis & $8.2 \pm 1.0$ & $1.94 \pm 0.17$ \\
V. victoriae & $12.6 \pm 2.4$ & $1.52 \pm 0.02$ \\
D. fristingensis & $3.6 \pm 0.2$ & $3.43 \pm 0.25$ \\
R. mucilaginosa & $5.8 \pm 0.3$ & $2.07 \pm 0.04^{*}$ \\
C. laryngis & $6.5 \pm 0.3$ & $2.44 \pm 0.09^{*}$ \\
S. salmonicolor & $5.0 \pm 0.6$ & $2.63 \pm 0.13$ \\
W. anomalus & $7.1 \pm 0.2$ & $2.23 \pm 0.08^{*}$ \\
G. gastrica & $8.7 \pm 0.8$ & $2.13 \pm 0.22^{*}$ \\
M. gelida & $3.2 \pm 0.2$ & $3.11 \pm 0.02$ \\
M. blollopis & $1.4 \pm 0.1$ & $6.91 \pm 0.24$ \\
\hline
\end{tabular}

a, normalized by dry weight of yeasts; ${ }^{\mathrm{b}}$, percentages calculated according to analysis by RP-HPLC. *, data from Villarreal et al. [38]. The values are the average of three determinations

to the retention time and absorbance spectrum (Additional file 4: Figure S2). These results indicate that M. blollopis and L. creatinivorum had the highest ergosterol content by yeast dry weight among the assayed strains, i.e., 6.9 and $4.0 \mathrm{mg} \mathrm{g}^{-1}$, respectively. However, considering the culture volume, the major ergosterol producers were $V$. victoriae, G. gastrica and L. creatinivorum, which produced 19.2, 18.5 and $16.1 \mathrm{mg} \mathrm{l}^{-1}$ of ergosterol, respectively.

\section{Discussion}

In this work, yeast species isolated from Antarctica were analyzed for the production of ice-binding proteins, unsaturated fatty acids and ergosterol, compounds associated with tolerance to cold and freezing conditions and that are economically attractive. From a physiological perspective, none of these metabolites alone could be correlated with the tolerance to freeze-thaw cycles performed in this study (Additional file 5: Figure S3), suggesting that there is a complex response to this stress that may involve other factors not analyzed in this study, such as the production of intracellular IBPs and compatible metabolites.

Antifreeze activity was detected in the secreted proteins of L. creatinivorum, C. parapsilosis, and G. gastrica. However, it is important to mention that if some of the studied yeasts secreted AFPs with a minor molecular weight $\geq 10 \mathrm{kDa}$, these could not be detected due to the purification methodology used in this study. In spite of this, our work increases the number of yeast species from which AFPs or antifreeze activity has been reported, which so far have been described only for Glaciozyma antarctica, Glaciozyma sp. AY30 (formerly Leucosporidium sp. AY30), and Rhodotorula glacialis [49]. AFPs were partially purified only from G. gastrica, in which at least three proteins with rMWs of 30,000 to 100,000 are responsible for this activity. The majority of antifreeze proteins described so far are small (less than $25 \mathrm{kDa}$ ) [15], and to the best of our knowledge, there are no reports describing several proteins acting together to produce antifreeze activity. These proteins maintained their antifreeze activity after several FTCs, a desirable characteristic for potential applications as additives for preserving the viability of frozen cells. The most studied IBP is a $26-\mathrm{kDa}$ glycosylated protein from an Artic Glaciozyma sp. [50], and its application in preserving several types of eukaryotic cells, including erythrocytes and mouse oocytes, has been documented [12, 51-53]. Commercially, natural and synthetic AFPs are expensive, and studies on those expressed in bacteria, yeast and insect

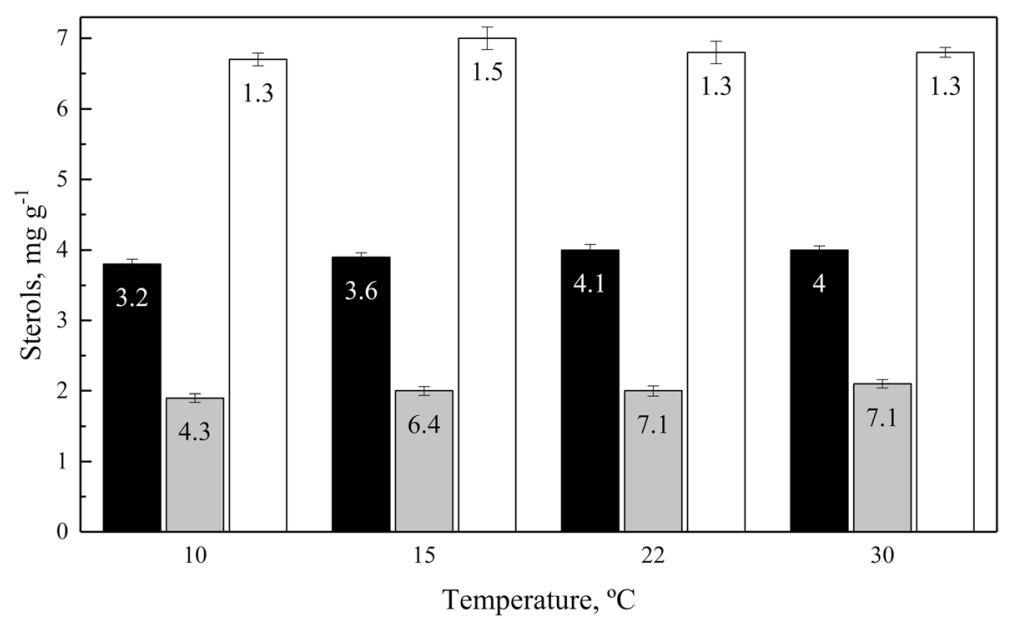

Fig. 5 Sterol contents in yeasts cultivated at different temperatures. The yeasts M. blollopis (white columns), L. creatinivorum (black columns), and R. mucilaginosa (grey columns) were grown until the early stationary phase of growth, and sterols were extracted and quantified from the cell pellets. The biomass (in $\mathrm{g}^{-1}$ ) reached by each culture at each assayed temperature is indicated in each column. The values are the average of three determinations, and the error bars correspond to the standard deviation 
cell culture systems are necessary for more efficient expression and scale-up production [54]. Furthermore, there is a constant search for IBPs with new properties for application in different fields, for which more in-depth characterization of the IBPs described here is necessary to evaluate their applicability.

One of the most studied adaptations of yeasts that live in cold environments is their lipid metabolism, which allows them to maintain membrane fluidity at low temperatures, an example of which is the increased production of unsaturated FAs [22]. In six of the Antarctic yeast species investigated in this study, the percentage of unsaturated FAs was higher than $70 \%$, which is consistent with others studies and indicates that Antarctic yeasts produce a higher proportion of unsaturated FAs than yeasts isolated from other environments [55-57]. Oleic, eicosanoic, linoleic and alpha-linoleic acids, which are economically important FAs since they must be incorporated in mammalian diets $[19,58,59]$, were all identified at high percentages in at least one of the yeast species analyzed in this work. Taking into account the total FAs, the percentages of PUFAs in the yeast species analyzed in this work ranged from 12 to $37 \%$, which are very high values compared to the $4 \%$ obtained in a genetically engineered strain of S. cerevisiae [60]. Alternatives to current sources of PUFAs are desirable to lower the cost of production and to eliminate the fishy flavor of PUFAs-fortified foods. Yeasts have many attributes that support the economic feasibility of their large-scale production, such as high growth rates and production yields using inexpensive growth media, as well as the ability to increase their productivity through culture optimization and genetic manipulations [61-63]. Although lipid or PUFA synthesis has been achieved through genetic engineering, the culture conditions that favor lipid accumulation, the high synthesis of PUFAs and cell growth are lacking, which limits large-scale economic production [64].

In all yeast species analyzed in this study, almost $100 \%$ of sterols found corresponded to ergosterol. Although the highest specific content of ergosterol was observed for $M$. blollopis, $V$. victoriae produced the highest amount of ergosterol per liter of culture. The commercial sources of ergosterol correspond to strains of S. cerevisiae; however, the ergosterol content is finely regulated in this yeast species at the transcriptional level, resulting in a low production [65]. The ergosterol contents of M. blollopis and $L$. creatinivorum were comparable to a genetically modified strain of S. cerevisiae [33, 34], raising the possibility of future improvements of their natural ergosterol production at an industrial scale through the modification of culture conditions.

\section{Conclusions}

From a physiological perspective, none of the compounds analyzed in this study may solely explain the freeze-thaw tolerance observed for the yeast species investigated, suggesting a complex response to this stress that may include other cellular mechanisms that were not considered. With respect to the production of economically important compounds, we identified yeasts that are good candidates for the industrial production of AFPs, PUFAs and ergosterol.

\section{Additional files}

Additional file 1: Figure S1. SDS-PAGE results of the proteins secreted by yeasts and their antifreeze properties. The corresponding yeast species from which the proteins sample were obtained and their BFR/AFR values are indicated at the top and bottom of the wells, respectively. $M$, protein molecular marker. (JPG 951 kb)

Additional file 2: Figure S2. Representative RP-HPLC chromatograms from sterol sample analyses. Yeasts with the highest (M. blollopis, continuous line) and the lowest ( $V$. victoriae discontinuous line) sterol contents were included. The absorbance spectra for the corresponding peaks are shown. (JPG 698 kb)

Additional file 3: Figure S3. Biplot of the two principal components derived from the biomolecular data. SFA, saturated fatty acids; MUFA, monounsaturated fatty acids; PUFA, polyunsaturated fatty acids; AP, antifreeze property; Erg, ergosterol. At each point, the tolerance to FTCs is indicated. In each case, the percentages were calculated considering the highest value as 100\%. (JPG $761 \mathrm{~kb}$ )

Additional file 4: Table S1. Yeast growth and production of extracellular proteins in different media. (DOCX 50 kb)

Additional file 5: Table S2. Saturated and monounsaturated fatty acid composition in Antarctic yeasts. (DOCX $17 \mathrm{~kb}$ )

\section{Abbreviations}

AFPs: Antifreeze proteins; AFR: The $A_{520} / A_{650}$ ratio after freezing; ALA: Alpha linoleic acid; AP: Antifreeze property; AuNPs: Gold nanoparticles; BFR: The

$A_{520} / A_{650}$ ratio before freezing; BSA: Bovine serum albumin; FAs: Fatty acids; FTC: Freeze-thaw cycle; IBPs: Ice-binding proteins; LA: Linoleic acid; MUFAs: Monounsaturated fatty acids; PUFAs: Polyunsaturated fatty acids; RPHPLC: Reverse-phase high performance liquid chromatography;

SFAs: Saturated fatty acids; VM: Vogel's minimal medium; YM: Yeast-malt medium; YNB: Yeast nitrogen base

\section{Funding}

Comisión Nacional de Investigación Científica y Tecnológica (CONICYT), Fondecyt grant no. 1130333. The funding bodies had no role in the design of the study and collection, analysis, and interpretation of data and in writing the manuscript.

Availability of data and materials

All data generated or analyzed in this study are included in this published article and in additional files.

\section{Authors' contributions}

MB conceived the study; PV, MC, and SB performed experimental procedures, including freeze-thaw tolerance assays, and the extraction and analysis of proteins, sterols and fatty acids; MB, PV and JA analyzed the results; MB, JA and VC wrote the manuscript. All authors read and approved the final manuscript.

Ethics approval and consent to participate Not applicable.

Consent for publication Not applicable. 


\section{Competing interests}

The authors declare that they have no competing interests.

\section{Publisher's Note}

Springer Nature remains neutral with regard to jurisdictional claims in published maps and institutional affiliations.

Received: 23 January 2018 Accepted: 27 June 2018

Published online: 05 July 2018

\section{References}

1. Jeon SM, Naing AH, Park Kl, Kim CK. The effect of antifreeze protein on the cryopreservation of chrysanthemums. Plant Cell Tissue Organ Cult. 2015;123: $665-71$.

2. Griffith M, Ewart KV. Antifreeze proteins and their potential use in frozen foods. Biotechnol Adv. 1995;13:375-402.

3. Bang JK, Lee JH, Murugan RN, Lee SG, Do H, Koh HY, Shim HE, Kim HC, Kim HJ. Antifreeze peptides and glycopeptides, and their derivatives: potential uses in biotechnology. Mar Drugs. 2013;11:2013-41.

4. DeVries AL, Wohlschlag DE. Freezing resistance in some Antarctic fishes. Science. 1969:163:1073-5.

5. Hoshino T, Kiriaki M, Ohgiya S, Fujiwara M, Kondo H, Nishimiya Y, Yumoto I, Tsuda S. Antifreeze proteins from snow mold fungi. Can J Bot. 2003;81: 1175-81.

6. Janech MG, Krell A, Mock T, Kang J-S, Raymond JA. Ice-binding proteins from sea ice diatoms(Bacillariophyceae). J Phycol. 2006;42:410-6.

7. Raymond JA. The ice-binding proteins of a snow alga, Chloromonas brevispina: probable acquisition by horizontal gene transfer. Extremophiles. 2014;18:987-94

8. Garnham CP, Gilbert JA, Hartman CP, Campbell RL, Laybourn-Parry J, Davies PL. A Ca2+-dependent bacterial antifreeze protein domain has a novel beta-helical ice-binding fold. Biochem J. 2008:411:171-80.

9. Gilbert JA, Hill PJ, Dodd CE, Laybourn-Parry J. Demonstration of antifreeze protein activity in Antarctic lake bacteria. Microbiology. 2004;150:171-80.

10. Raymond JA, Fritsen C, Shen K. An ice-binding protein from an Antarctic Sea ice bacterium. FEMS Microbiol Ecol. 2007:61:214-21.

11. Kawahara H, Iwanaka Y, Higa S, Muryoi N, Sato M, Honda M, Omura H, Obata H. A novel, intracellular antifreeze protein in an Antarctic bacterium, Flavobacterium xanthum. CryoLetters. 2007;28:39-49.

12. Lee SG, Koh HY, Lee $\mathrm{H}$, Kang SH, Kim HJ. Cryopreservative effects of the recombinant ice-binding protein from the arctic yeast Leucosporidium sp. on red blood cells. Appl Biochem Biotechnol. 2012;167:824-34.

13. Lee JH, Park AK, Do H, Park KS, Moh SH, Chi YM, Kim HJ. Structural basis for antifreeze activity of ice-binding protein from arctic yeast. J Biol Chem. 2012;287:11460-8.

14. Hashim NH, Bharudin I, Nguong DL, Higa S, Bakar FD, Nathan S, Rabu A, Kawahara H, Illias RM, Najimudin N, Mahadi NM, Murad AM. Characterization of Afp1, an antifreeze protein from the psychrophilic yeast Glaciozyma antarctica PI12. Extremophiles. 2013:17:63-73.

15. Bar Dolev M, Braslavsky I, Davies P. Ice-binding proteins and their function Annu Rev Biochem. 2016;2:515-42.

16. Davies PL, Baardsnes J, Kuiper MJ, Walker VK. Structure and function of antifreeze proteins. Philos Trans R Soc Lond Ser B Biol Sci. 2002;357:927-35.

17. Kar RK, Mroue KH, Kumar D, Tejo BA, Bhunia A. Structure and dynamics of antifreeze protein-model membrane interactions: a combined spectroscopic and molecular dynamics study. J Phys Chem B. 2016;120: 902-14

18. Venketesh S, Dayananda C. Properties, potentials, and prospects of antifreeze proteins. Crit Rev Biotechnol. 2008;28:57-82.

19. Wiktorowska-Owczarek A, Berezińska M, Nowak JZ. PUFAs: structures, metabolism and functions. Adv Clin Exp Med. 2015;24:931-41.

20. Akpinar-Bayizit A. Fungal lipids: the biochemistry of lipid accumulation. Int J Chem Engi App. 2014;5:409-14

21. Alcaíno J, Cifuentes V, Baeza M. Physiological adaptations of yeasts living in cold environments and their potential applications. World J Microbiol Biotechnol. 2015;31:1467-73.

22. Rossi M, Buzzini P, Cordisco L, Amaretti A, Sala M, Raimondi S, Ponzoni C, Pagnoni UM, Matteuzzi D. Growth, lipid accumulation, and fatty acid composition in obligate psychrophilic, facultative psychrophilic, and mesophilic yeasts. FEMS Microbiol Ecol. 2009;69:363-72.
23. Chen M, Thelen JJ. Acyl-lipid desaturase2 is required for chilling and freezing tolerance in Arabidopsis. Plant Cell. 2013;25:1430-44.

24. He J, Yang Z, Hu B, Ji X, Wei Y, Lin L, Zhang Q. Correlation of polyunsaturated fatty acids with the cold adaptation of Rhodotorula glutinis. Yeast. 2015;32:683-90

25. Patil D. Recent trends in production of polyunsaturated fatty acids (PUFA) concentrates. J Food Res Technol. 2014;2:15-23.

26. Sakuradani E. Advances in the production of various polyunsaturated fatty acids through oleaginous fungus Mortierella alpina breeding. Biosci Biotechnol Biochem. 2010;74:908-17.

27. Barros MP, Poppe SC, Bondan EF. Neuroprotective properties of the marine carotenoid astaxanthin and omega-3 fatty acids, and perspectives for the natural combination of both in krill oil. Nutrients. 2014:6:1293-317.

28. Dupont S, Lemetais G, Ferreira T, Cayot P, Gervais P, Beney L. Ergosterol biosynthesis: a fungal pathway for life on land. Evolution. 2012;66:2961-8.

29. Kelly D, Kelly S. Rewiring yeast for drug synthesis. Nat Biotechnol. 2003; 21:133-4.

30. Subbiah MT, Abplanalp W. Ergosterol (major sterol of baker's and brewer's yeast extracts) inhibits the growth of human breast cancer cells in vitro and the potential role of its oxidation products. Int J Vitam Nutr Res. 2003;73:19-23.

31. Chen S, Yong T, Zhang Y, Su J, Jiao C, Xie Y. Anti-tumor and anti-angiogenic Ergosterols from Ganoderma lucidum. Front Chem. 2017:5:85.

32. Li X, Wu Q, Xie Y, Ding Y, Du WW, Sdiri M, Yang BB. Ergosterol purified from medicinal mushroom Amauroderma rude inhibits cancer growth in vitro and in vivo by up-regulating multiple tumor suppressors. Oncotarget. 2015; 6:17832-46

33. He X, Guo X, Liu N, Zhang B. Ergosterol production from molasses by genetically modified Saccharomyces cerevisiae. Appl Microbiol Biotechnol. 2007;75:55-60.

34. Náhlík J, Hrnčiřík P, Mareš J, Rychtera M, Kent CA. Towards the design of an optimal strategy for the production of ergosterol from Saccharomyces cerevisiae yeasts. Biotechnol Prog. 2017;33:838-48.

35. Holdgate MW. Terrestrial ecosystems in the Antarctic. Philos Trans R Soc Lond Ser B Biol Sci. 1977;279:5-25.

36. Ruisi S, Barreca D, Selbmann L, Zucconi L, Onofri S. Fungi in Antarctica. Rev Environ Sci Biotechnol. 2007:6:127-41

37. Carrasco M, Alcaíno J, Cifuentes V, Baeza M. Purification and characterization of a novel cold adapted fungal glucoamylase. Microb Cell Factories. 2017:16:75.

38. Carrasco M, Alcaíno J, Cifuentes V, Baeza M. Purification and characterization of a novel a-glucosidase from an Antarctic yeast Dioszegia fristingensis isolate. Amylase. 2017;1:50-8

39. Troncoso E, Barahona S, Carrasco M, Villarreal P, Alcaíno J, Cifuentes V, Baeza M. Identification and characterization of yeasts isolated from the south Shetland Islands and the Antarctic peninsula. Polar Biol. 2017:40:649-58.

40. Villarreal P, Carrasco M, Barahona S, Alcaíno J, Cifuentes V, Baeza M. Tolerance to ultraviolet radiation of psychrotolerant yeasts and analysis of their carotenoid, mycosporine, and ergosterol content. Curr Microbiol. 2016; 72:94-101.

41. Carrasco M, Villarreal P, Barahona S, Alcaíno J, Cifuentes V, Baeza M. Screening and characterization of amylase and cellulase activities in psychrotolerant yeasts. BMC Microbiol. 2016;16:21.

42. Barahona S, Yuivar Y, Socias G, Alcaíno J, Cifuentes V, Baeza M. Identification and characterization of yeasts isolated from sedimentary rocks of union glacier at the Antarctica. Extremophiles. 2016;20:479-91.

43. Carrasco M, Rozas JM, Barahona S, Alcaíno J, Cifuentes V, Baeza M. Diversity and extracellular enzymatic activities of yeasts isolated from king George Island, the sub-Antarctic region. BMC Microbiol. 2012;12:251.

44. Park Jl, Lee JH, Gwak Y, Kim HJ, Jin E, Kim YP. Frozen assembly of gold nanoparticles for rapid analysis of antifreeze protein activity. Biosens Bioelectron. 2013:41:752-7.

45. Mitchell DE, Congdon T, Rodger A, Gibson MI. Gold nanoparticle aggregation as a probe of antifreeze (glyco) protein-inspired ice recrystallization inhibition and identification of new IRI active macromolecules. Sci Rep. 2015:5:15716.

46. Shang F, Wen S, Wang X, Tan T. Effect of nitrogen limitation on the ergosterol production by fed-batch culture of Saccharomyces cerevisiae. J Biotechnol. 2006;122:285-92.

47. Venkateswarlu K. The N-terminal membrane domain of yeast NADPHcytochrome P450 (CYP) oxidoreductase is not required for catalytic activity 
in sterol biosynthesis or in reconstitution of CYP activity. J Biol Chem. 1998; 273:4492-6.

48. Bligh EG, Dyer WJ. A rapid method of total lipid extraction and purification. Can J Biochemi Physiol. 1959;37:911-7.

49. Kim HJ, Lee JH, Do H, Jung W. Production of antifreeze proteins by coldadapted yeasts. In: Cold-adapted yeasts. Berlin: Springer Berlin Heidelberg; 2014. p. 259-80,

50. Lee JK, Park KS, Park S, Park H, Song YH, Kang SH, Kim HJ. An extracellular ice-binding glycoprotein from an Arctic psychrophilic yeast. Cryobiology. 2010;60:222-8.

51. Kim HJ, Shim HE, Lee JH, Kang YC, Hur YB. Ice-binding protein derived from Glaciozyma can improve the viability of cryopreserved mammalian cells. J Microbiol Biotechnol. 2015;25:1989-96.

52. Koh HY, Lee JH, Han SJ, Park H, Lee SG. Effect of the antifreeze protein from the arctic yeast Leucosporidium sp. AY30 on cryopreservation of the marine diatom Phaeodactylum tricornutum. Appl Biochem Biotechnol. 2015;175:677-86.

53. Lee HH, Lee HJ, Kim HJ, Lee JH, Ko Y, Kim SM, Lee JR, Suh CS, Kim S. Effects of antifreeze proteins on the vitrification of mouse oocytes: comparison of three different antifreeze proteins. Hum Reprod. 2015;30:2110-9.

54. Cheung RCF, Ng TB, Wong JH. Antifreeze proteins from diverse organisms and their applications: an overview. Curr Protein Pept Sci. 2017;18:262-83.

55. Zlatanov M, Pavlova K, Antova G, Angelova-Romova M, Georgieva K, Rousenova-Videva S. Biomass production by Antarctic yeast strains: an investigation on the lipid composition. Biotechnol Biotechnol Eq. 2014;24: 2096-101.

56. Thomas-Hall S. Cryptococcus nyarrowii sp. nov., a basidiomycetous yeast from Antarctica. Int J System Evol Microbiol. 2002;52:1033-8.

57. Bhuiyan M, Tucker D, Watson K. Gas chromatography-mass spectrometry analysis of fatty acid profiles of Antarctic and non-Antarctic yeasts. Antonie Van Leeuwenhoek. 2014;106:381-9.

58. Håvard B. Dietary polyunsaturated fatty acids, brain function and mental health. Microb Ecol Health Disease. 2017;28:1281916.

59. Bazinet RP, Layé S. Polyunsaturated fatty acids and their metabolites in brain function and disease. Nat Rev Neurosci. 2014:15:771-85.

60. Ruenwai R, Neiss A, Laoteng K, Vongsangnak W, Dalfard AB, Cheevadhanarak S, Petranovic D, Nielsen J. Heterologous production of polyunsaturated fatty acids in Saccharomyces cerevisiae causes a global transcriptional response resulting in reduced proteasomal activity and increased oxidative stress. Biotechnol J. 2011;6:343-56.

61. Gurung N, Ray S, Bose S, Rai V. A broader view: microbial enzymes and their relevance in industries, medicine, and beyond. Biomed Res Int 2013; 2013:329121.

62. Adrio JL, Demain AL. Microbial enzymes: tools for biotechnological processes. Biomol Ther. 2014;4:117-39.

63. Anbu P, Gopinath SCB, Cihan AC, Chaulagain BP. Microbial enzymes and their applications in industries and medicine. Biomed Res Int. 2013;2013:1-2.

64. Bellou S, Triantaphyllidou IE, Aggeli D, Elazzazy AM, Baeshen MN, Aggelis G. Microbial oils as food additives: recent approaches for improving microbial oil production and its polyunsaturated fatty acid content. Curr Opin Biotechnol. 2016;37:24-35.

65. Daum G, Lees ND, Bard M, Dickson R. Biochemistry, cell biology and molecular biology of lipids of Saccharomyces cerevisiae. Yeast. 1998;14:1471-510.

\section{Ready to submit your research? Choose BMC and benefit from:}

- fast, convenient online submission

- thorough peer review by experienced researchers in your field

- rapid publication on acceptance

- support for research data, including large and complex data types

- gold Open Access which fosters wider collaboration and increased citations

- maximum visibility for your research: over $100 \mathrm{M}$ website views per year

At BMC, research is always in progress.

Learn more biomedcentral.com/submissions 